\title{
Climatology of the aerosol optical depth by components from the Multi-angle Imaging SpectroRadiometer (MISR) and chemistry transport models
}

\author{
Huikyo Lee $^{1}$, Olga V. Kalashnikova ${ }^{1}$, Kentaroh Suzuki ${ }^{2}$, Amy Braverman ${ }^{1}$, Michael J. Garay ${ }^{1}$, and Ralph A. Kahn ${ }^{3}$ \\ ${ }^{1}$ Jet Propulsion Laboratory, California Institute of Technology, Pasadena, California, USA \\ ${ }^{2}$ Atmosphere and Ocean Research Institute, University of Tokyo, Kashiwa, Japan \\ ${ }^{3}$ Laboratory for Atmospheres, NASA Goddard Space Flight Center, Greenbelt, Maryland, USA
}

Correspondence to: Huikyo Lee (huikyo.lee@jpl.nasa.gov)

Received: 9 November 2015 - Published in Atmos. Chem. Phys. Discuss.: 1 December 2015

Revised: 17 May 2016 - Accepted: 18 May 2016 - Published: 1 June 2016

\begin{abstract}
The Multi-angle Imaging SpectroRadiometer (MISR) Joint Aerosol (JOINT_AS) Level 3 product has provided a global, descriptive summary of MISR Level 2 aerosol optical depth (AOD) and aerosol type information for each month over 16+ years since March 2000. Using Version 1 of JOINT_AS, which is based on the operational (Version 22) MISR Level 2 aerosol product, this study analyzes, for the first time, characteristics of observed and simulated distributions of AOD for three broad classes of aerosols: spherical nonabsorbing, spherical absorbing, and nonspherical - near or downwind of their major source regions. The statistical moments (means, standard deviations, and skewnesses) and distributions of AOD by components derived from the JOINT_AS are compared with results from two chemistry transport models (CTMs), the Goddard Chemistry Aerosol Radiation and Transport (GOCART) and SPectral RadIatioN-TrAnSport (SPRINTARS). Overall, the AOD distributions retrieved from MISR and modeled by GOCART and SPRINTARS agree with each other in a qualitative sense. Marginal distributions of AOD for each aerosol type in both MISR and models show considerable high positive skewness, which indicates the importance of including extreme AOD events when comparing satellite retrievals with models. The MISR JOINT_AS product will greatly facilitate comparisons between satellite observations and model simulations of aerosols by type.
\end{abstract}

\section{Introduction}

Atmospheric aerosol distributions and temporal variations play fundamental roles in Earth's climate system. Direct radiative forcing of aerosol scattering and absorption of shortwave radiation is estimated at around $-0.7 \mathrm{~W} \mathrm{~m}^{-2}$ from reanalysis data (Bellouin et al., 2013) and $-1.3 \mathrm{~W} \mathrm{~m}^{-2}$ based on satellite observations (Bellouin et al., 2008). In addition, aerosols affect radiative forcing indirectly by changing the microphysical properties of clouds and precipitation. Studies of aerosol impacts on large-scale circulation have brought further attention to interactions between aerosols and clouds. For example, Li et al. (2008) shows that the recent positive trend in wintertime precipitation over the North Pacific is related to increased aerosol emissions. Zhang et al. (2007) and Wang et al. (2014) suggest that increased anthropogenic aerosol emissions in Asia can strengthen cyclones along the Pacific storm track. Both direct and indirect radiative forcing of aerosols are expected to be more important under a changing climate. For example, Ganor et al. (2010) and $\mathrm{Lu}$ et al. (2010) report increasing dust aerosols in Africa and sulfate aerosols in China, respectively. However, global climate models (GCMs) have a hard time producing consistent radiative forcing responses to varying concentrations of aerosols (IPCC, 2013). In fact, indirect radiative forcing due to aerosols is one of the dominant sources of uncertainty in the energy budget of many GCMs (Regayre et al., 2014).

Despite substantial improvements in the representation of physical and chemical processes related to aerosols in globalscale chemistry models relative to most GCMs, recent work 
has shown that such models still exhibit considerable biases and uncertainties in aerosol concentrations and related radiative forcings (Lee et al., 2013; Shindell et al., 2013). Therefore, validating simulated aerosols in chemistry models is critical in order to better understand the root causes of these biases and uncertainties.

Aerosol-radiation interactions are determined by the size distribution of aerosols, as well as their shape and lightabsorption properties (Boucher et al., 2013). Understanding the optical and microphysical characteristics of natural and anthropogenic aerosols is critical for advancing the ability of chemistry climate models (CCMs) to correctly simulate the climate impact of aerosols. Nevertheless, many previous studies evaluating simulated aerosol optical depth (AOD) in models against satellite observations, such as those available from the Moderate Resolution Imaging Spectroradiometer (MODIS) and the Multi-angle Imaging SpectroRadiometer (MISR), have used only the total column AOD without taking aerosol type information into account (e.g., Tilmes et al., 2015). Shindell et al. (2013) compared AODs for each aerosol type simulated in nine CCMs. Not surprisingly, the difference in component AODs among models is much greater than the difference in total AODs (see Fig. 3 in Shindell et al., 2013). To understand the diverse partitioning of AOD among dust, sea salt, sulfate, nitrate, black carbon, and organic carbon in CCMs, it is important to compare the simulated component AODs against global climatological maps of observed AOD by components, to the extent that it is possible.

Unfortunately, the retrieval of AOD by type from satellite observations and using the retrieved AOD for chemistry model evaluation have been, and remain, significant challenges. Aerosol polarization measurement by the POLDER3 (POLarization and Directionality of the Earth Reflectance) instrument on board the PARASOL (Polarization and Anisotropy of Reflectances for Atmospheric Sciences coupled with Observations from a Lidar) enables observed aerosols to be classified into various types (Russell et al., 2014). CALIPSO (Cloud-Aerosol Lidar and Infrared Pathfinder Satellite Observation) also provides aerosol classification from backscatter and depolarization measurements, plus some geographical constraints (Omar et al., 2009). Higurashi and Nakajima (2002) suggest detecting a dominant aerosol type using radiances from four spectral channels on the Sea-viewing Wide Field-of-view Sensor (SeaWiFS). Kim et al. (2007) used both MODIS observations and data from the Ozone Monitoring Instrument (OMI) to classify retrieved aerosol types, but the algorithm was similarly limited to providing a single, dominant aerosol type. Even these state-of-the-art satellite observations providing information on AOD by components cannot be readily compared with simulated AOD for different aerosol types. The aerosol type in satellite retrievals is defined by optical properties, whereas the simulated aerosol type is specified by chemical composition. As a result, in the AOD climatology by type reconstructed in Nabat et al. (2013), total AOD is from a satellite instrument, but the AOD by type is partitioned solely from the fractions of the five aerosol types (sulfate, black carbon, organic carbon, dust, and sea salt) simulated in two CCMs. Holzer-Popp et al. (2008) provides an overview of currently available aerosol type data sets from satellites, and combined data from the Advanced Along-Track Scanning Radiometer (AATSR) and the Scanning Imaging Absorption Spectrometer for Atmospheric Chartography (SCIAMACHY) on board the European Environmental Satellite (ENVISAT) to produce total column AOD and speciation by aerosol mixtures. In their study, total column AOD and surface reflectivity were derived from AATSR observations and these variables were used to simulate spectra for predefined aerosol mixtures, which were selected by comparison with the observed SCIAMACHY spectra.

Due to its unique multi-angle viewing approach, the MISR instrument on NASA's Terra satellite is capable of distinguishing mixtures of aerosol types without relying on data from other instruments (Kahn et al., 2001; Diner et al., 2005a). MISR measures radiation in four spectral bands (blue $-446 \mathrm{~nm}$, green $-558 \mathrm{~nm}$, red $-672 \mathrm{~nm}$, and nearinfrared $-866 \mathrm{~nm}$ ) from nine different viewing directions $\left( \pm 70.5, \pm 60.0, \pm 45.6, \pm 26.1\right.$, and $0.0^{\circ}$ along the direction of satellite motion), allowing retrievals of aerosol particle size and shape (Kahn et al., 2001; Diner et al., 2005b). The operational (Version 22) aerosol retrieval algorithm is based on matching observed top of atmosphere (TOA) radiances to radiances modeled for AODs ranging from 0.0 to 3.0 from 74 "mixtures", each defined as up to the three of eight "pure" particle types, or "components", in specific mid-visible AOD proportions. Each component represents a single size distribution having specific optical properties (Kahn et al., 2010). There are optical models for four spherical nonabsorbing components of different sizes, two spherical absorbing components with different single-scattering albedos, and two nonspherical dust optical analogs. Within the algorithm, a mixture is acceptable, or "passing", if the difference between the observed and modeled radiances is less than a predetermined value. In the Level 2 (swath) product, the mean AOD of the passing mixtures is reported in the field "RegBestEstimateSpectralOptDepth" at a spatial resolution of $17.6 \mathrm{~km} \times 17.6 \mathrm{~km}$. The best-fitting mixture out of the 74 candidate mixtures is reported as the "RegLowestResidMixture", but the AOD and information about which mixtures were considered passing are retained in the fields "OptDepthPerMixture" and "AerRetrSuccFlagPerMixture", respectively, for further evaluation. Validation of the Level 2 Version 22 product against ground-based observations from the Aerosol Robotic Network (AERONET) (Holben et al., 1998), including assessments of particle type retrievals, can be found in Kahn et al. (2010) and Kahn and Gaitley (2015). The mixture type information in the MISR Version 22 aerosol product has been exploited by $\mathrm{Li}$ et al. (2013) and Li et al. (2015), for example, who used CCM in- 
formation to select from the complete set of passing mixtures to improve agreement with AERONET in the continental United States.

The main objective of the current study is to compare multi-year MISR AOD climatologies with simulated AODs, partitioned by aerosol type. The results of this work highlight the added value of using AOD by components from MISR in evaluating chemistry transport models (CTMs) and CCMs. Due to the relatively short lifetime of aerosols compared to trace gases, it is also important to consider the spatial inhomogeneity of aerosol distributions and resulting regional effects. MISR's aerosol type information becomes more reliable in the regions where AOD exceeds about 0.15 and 0.2 (Kahn et al., 2010; Kahn and Gaitley, 2015). Therefore, here we focus, in particular, on characterizing AOD distributions in regions near major aerosol emission sources: East Asia, the Sahara, and West Africa, with comparisons between MISR climatological observations and two model simulations. One is from the Goddard Chemistry Aerosol Radiation and Transport (GOCART) model (Chin et al., 2002, 2014), and the other is from the SPectral RadIatioNTrAnSport (SPRINTARS) model for Aerosol Species (Takemura et al., 2002, 2005) interactively coupled to the Nonhydrostatic Icosahedral Atmospheric Model (NICAM) (Satoh et al., 2008, 2014; Suzuki et al., 2008). We also demonstrate why it is important to consider spatiotemporal distributions of AOD when comparing satellite observations and models rather than simply using spatially and temporally averaged AODs for model evaluation.

The remainder of the paper is structured as follows. The data and models used in this study are described in Sect. 2. Comparisons between MISR retrievals and model simulations are presented in Sect. 3, followed by a summary of key findings in Sect. 4.

\section{Data}

\subsection{MISR Level 3 Joint Aerosol product}

As the MISR mission progresses, and more observations become available for model intercomparison projects such as AeroCom (Schulz et al., 2006; Myhre et al., 2013), the Coupled Model Intercomparison Project Phase 5 (CMIP5) (Taylor et al., 2012), and the Atmospheric Chemistry and Climate Model Intercomparison Project (ACCMIP) (Lamarque et al., 2013), it is important that these data become more accessible (Teixeira et al., 2014). Getting the mixture information from the MISR Level 2 aerosol product is an indirect procedure, requiring access to Hierarchical Data Format (HDF) Vertex Data (VDATA) fields that map integer-valued mixture identifiers in the MISR Level 2 files to the corresponding components and corresponding mixing proportions. To make this information more readily available, and to reduce the overall data volume required for large-scale analysis, the MISR project provides a Level 3 (gridded) Joint Aerosol Product (JOINT_AS) that summarizes the Level 2 aerosol retrievals on a monthly, $5^{\circ} \times 5^{\circ}$ latitude-longitude spatiotemporal grid. "Joint" refers to the joint distributions of aerosol types reported in this product, and "AS" refers to the MISR AerosolSurface algorithm that produces the original Level 2 product from which JOINT_AS is derived. The contents of the JOINT_AS product can be thought of as eight-dimensional histograms summarizing a large number of retrievals in every grid cell. The summarization algorithm is based on Braverman and Di Girolamo (2002). Each grid cell in the product contains a set of representative vectors and their associated weights in what is essentially a multidimensional probability distribution. The representative vectors have eight elements, which are the mid-visible $(558 \mathrm{~nm})$ AODs assigned to the eight components in the MISR algorithm climatology. These eight components include four nonabsorbing spherical particle optical analogs, with size distributions with effective radii of $0.06,0.12,0.26$, and $2.80 \mu \mathrm{m}$; two spherical absorbing particle analogs, both with size distributions with an effective radius of $0.12 \mu \mathrm{m}$ and single-scattering albedos of 0.9 and 0.8 in the mid-visible; and two nonspherical-particle size distributions corresponding to dust, one of grains with an effective radius of $0.75 \mu \mathrm{m}$, and the other of spheroids with an effective radius of $3.32 \mu \mathrm{m}$ (Kahn et al., 2010; Kahn and Gaitley, 2015).

Conceptually, one can think of the JOINT_AS product as being created as follows. For a given grid cell, all mixtures that pass the algorithm acceptance criteria are transformed into an eight vector that aggregates component-AOD proportions across mixtures, to yield total proportions of each component. Next, these proportions are multiplied by the total retrieved mid-visible AOD ("RegBestEstimateSpectralOptDepth") to create an eight vector of AODs that sums to the total reported AOD. To summarize the multidimensional distribution of AOD, the JOINT_AS product uses a clustering algorithm to partition the eight vectors into groups with similar members. These are effectively new, statistically representative mixtures of the eight components. A detailed description of the clustering algorithm used to generate the JOINT_AS can be found in Braverman (2002). In this study, we use Version 1 of the MISR JOINT_AS, based on the operational (Version 22) Level 2 MISR aerosol retrievals, for all months during the 15-year period from March 2000 through February 2015. When comparing MISR JOINT_AS with model simulations, we used the data for the 8 -year period between 2000 and 2007.

Figure 1 shows an example of how a two-dimensional subset of the eight-dimensional histogram contained within the MISR JOINT_AS product can be visualized as a scatter plot of absorbing, spherical-particle AOD plotted against nonabsorbing, spherical-particle AOD over East Asia for the month of April. One-dimensional AOD sampling distributions are shown as the histogram at the top of the figure for nonabsorbing, spherical particles and to the right of the figure, 


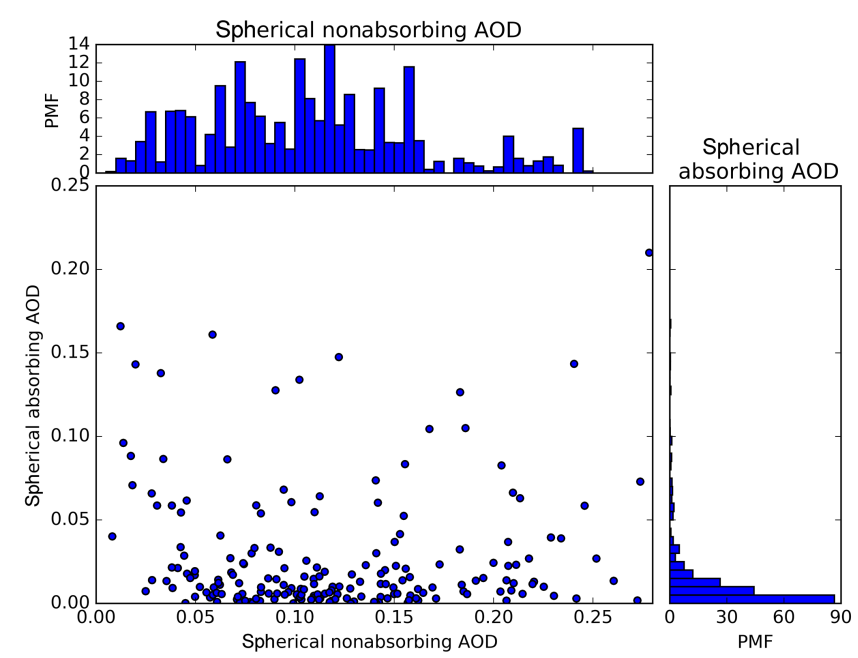

Figure 1. A scatter plot of spherical absorbing-component AOD and spherical nonabsorbing-component AOD at $558 \mathrm{~nm}$ wavelength and their histograms over East Asia $\left(117.5-127.5^{\circ} \mathrm{E}, 32.5-42.5^{\circ} \mathrm{N}\right)$ in April between 2000 and 2014. The AOD data are from MISR Version 1 of the Level 3 Joint Aerosol product (JOINT_AS) based on the Version 22 operational Level 2 aerosol retrievals. The two histograms for spherical nonabsorbing and absorbing-component AOD are scaled to show a probability mass function (PMF) so that the total area of the bars in each histogram becomes one.

AOD for spherical absorbing particles. The scatter plot itself shows how these two aerosol types co-vary in this region for the chosen time period. From the histograms, the MISR V22 product identifies nonabsorbing, spherical particles as the dominant aerosol component, with AOD that tends to span the range from about 0.025 to 0.15 , whereas retrieved absorbing AOD contributes only less than about 0.02 to the total AOD, in part due to relatively low sensitivity to particle single-scattering albedo (SSA) in most remote-sensing retrievals, and in part to limitations in the MISR Version 22 algorithm climatology, which contains very few absorbingaerosol components, so SSA tends to be overestimated when absorbing particles are present (Kahn et al., 2010; Kahn and Gaitley, 2015), though absorbing fraction of the total AOD also tends to be less than the scattering fraction. Because of this, there is very little covariance between the absorbingand nonabsorbing-component AODs in this case. In other words, the changes in retrieved nonabsorbing AOD over the area are not related to retrieved absorbing $\mathrm{AOD}$, at least based on the MISR V22 product.

Note that for comparisons with models, in this study we sum the total optical depth for spherical nonabsorbing, spherical absorbing, and nonspherical aerosols as the three highest-level aerosol-type categories in the MISR climatology. However, the absorbing AOD for a given retrieval is defined as the sum over all components, $\sum_{\text {components }}(1-$ SSA) $\times($ component AOD); so, for example, particles with
SSA $=0.8$ would only contribute $20 \%$ of their AOD to absorption.

From the information used to construct the marginal histograms, it is simple to calculate the moments (mean, variance, and skewness) of the AOD distributions for different aerosol types. The $k$ th central moment of the distribution $\left(M_{k}\right)$ with a sample size, $N$, is conventionally defined as follows:

first moment (mean) $=\bar{x}=\frac{1}{N} \sum_{j=1}^{N} x_{j}$

$k$ th central moment $=M_{k}=\frac{1}{N} \sum_{j=1}^{N}\left(x_{j}-\bar{x}\right)^{k}$,

where $x_{j}$ corresponds to the $j$ th AOD. Using the above definitions, the skewness of the distribution can be represented as

skew $=N \frac{M_{3}}{M_{2}{ }^{1.5}}$.

If the data follow a normal (Gaussian) distribution, the skewness of the data should be close to zero. If a distribution has positive skewness, the tail representing values larger than the median of the distribution is longer than the tail representing smaller values. Conversely, if the distribution has a negative skewness, the tail representing smaller values is enhanced. If the skewness of the distribution is not close to zero, the mean and standard deviation are not enough to appropriately represent the distribution. For a normal distribution the standard deviation of the sample skewness is approximately $\sqrt{15 / N}$, where $N$ is the sample size. Skewness values less than a few times as large as this (e.g., $\mid$ skew $\mid<3$ for a sample size of 15) should be viewed with suspicion. On the other hand, when the distribution of data is highly skewed, this indicates that it is necessary to analyze individual values or at least a summary histogram of the data in order to understand how the data are actually distributed. As we will show, the ability to easily determine the moments and distributions of the MISR AODs by three general categories (spherical nonabsorbing, spherical absorbing, and nonspherical) is an important feature of the JOINT_AS product.

\subsection{Models}

In this study, we compare the AOD by components from the JOINT_AS product with results from two CTMs. Unlike CCMs, which generate their own meteorological fields, CTMs require meteorological input from another GCM. The GOCART simulation used here has a horizontal resolution of $2.5^{\circ} \times 1.5^{\circ}$, and is driven by meteorology fields from the Goddard Earth Observing System - Data Assimilation system (GEOS-DAS). The GOCART model used the emission data provided for the AeroCom Phase II model experiments (Diehl et al., 2012) for the 8-year period between 2000 and 
2007. The GOCART CTM includes the sulfur chemistry reactions from Muller and Brasseur (1995), such as DMS$\mathrm{OH}, \mathrm{SO}_{2}-\mathrm{OH}$, and $\mathrm{SO}_{2}-\mathrm{H}_{2} \mathrm{O}_{2}$ reactions, to simulate chemical production of sulfate aerosols. The model output provides daily optical depths of total aerosols, black carbon, dust, organic aerosols, sulfate, and sea salt at a wavelength of $550 \mathrm{~nm}$.

We also compare the MISR JOINT_AS product to the SPRINTARS CTM because of the model's unusually high spatial and temporal resolution; although the SPRINTARS detail will average out in the comparison, in some respects the aggregated data might provide a more accurate speciesspecific AOD picture. SPRINTARS simulation is coupled to the high-resolution NICAM model, which reports AOD at $550 \mathrm{~nm}$ wavelength every $3 \mathrm{~h}$ for four different aerosol types (carbonaceous, dust, sea salt, and sulfate), with a horizontal resolution of $7 \mathrm{~km}$ globally. Similar to the GOCART, the chemical reactions to form sulfate aerosols include the DMS-OH, $\mathrm{SO}_{2}-\mathrm{OH}, \mathrm{SO}_{2}-\mathrm{O}_{3}$, and $\mathrm{SO}_{2}-\mathrm{H}_{2} \mathrm{O}_{2}$ reactions. The detailed rate constants can be found in Table 4 of Takemura et al. (2000). As described by Suzuki et al. (2008), the SPRINTARS CTM reasonably reproduces global distributions of total AOD in comparison with MODIS near major aerosol emission sources. SPRINTARS is also one of the models included in the AeroCom intercomparison (Huneeus et al., 2011). However, due to computational limitations, the SPRINTARS simulation period available for this study only covers the 8 days from 1 July through 8 July 2006. In addition, we found that the JOINT_AS product for the single month of July 2006 contains a significant number of missing values, even at $5^{\circ} \times 5^{\circ}$ spatial resolution. The missing data are likely due to cloud screening and locations being flagged as inappropriate for aerosol retrievals, as discussed in Kahn et al. (2009). To enable the comparison between MISR and SPRINTARS, we had to aggregate the MISR data for multiple Julys, and assume that the AOD distribution does not change significantly from one year to the next during the month of July (the stationarity assumption). However, stationarity does not hold near the major aerosol emission sources, as shown later in the eastern Atlantic part of the Results section; so we view the results of the SPRINTARS comparison as an adjunct to the GOCART comparison.

It is important to note that the aerosol types in the GOCART and SPRINTARS models are different from the components used in the operational MISR aerosol retrievals (see Table 1 of Kahn and Gaitley, 2015). In order to compare the MISR AOD by components with those of the models, MISR aerosol types were combined in the manner shown in Table 1 . AODs from weakly and strongly absorbing spherical aerosols in the MISR data set, with SSA in the mid-visible of 0.9 and 0.8 , respectively, were combined to construct an analog to modeled carbonaceous aerosols. The combination of the more absorbing and less absorbing spherical particles is intended to represent the range of such particles in nature (e.g., Liu et al., 2014). Given the limited nonspherical dust
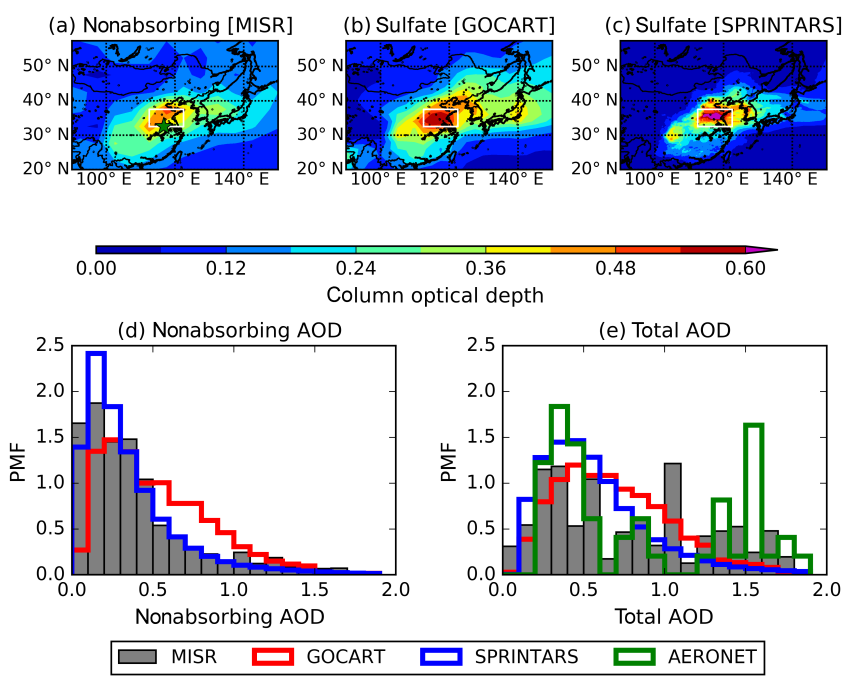

Figure 2. (a) Climatological mean optical depth of the spherical nonabsorbing aerosol components in MISR, sulfate aerosol optical depth in (b) GOCART, and (c) SPRINTARS over East Asia for July. Data from the eight Julys between 2000 and 2007 are averaged for MISR and GOCART. Spatiotemporal distributions of (d) the nonabsorbing (or sulfate) AOD and (e) total AOD from MISR (gray bars), from GOCART (red lines) and from SPRINTARS (blue lines), covering the boxed emission source region $\left(112.5-122.5^{\circ} \mathrm{E}, 32.5\right.$ $37.5^{\circ} \mathrm{N}$ ) are displayed. The green star in (a) displays a location of the AERONET station in Shouxian. The green line in (e) represents the total AOD distribution in Shouxian for July 2008.

models in the MISR operational retrieval, the AODs from the nonspherical grains and coarse spheroids from MISR (Kalashnikova et al., 2005) were combined. Finally, AODs from the three (small) nonabsorbing spherical particles were added to compare to the modeled sulfate aerosols. The largest MISR particle type, with an effective radius of $2.8 \mu \mathrm{m}$, was excluded when calculating the nonabsorbing AOD due to issues with retrieval sensitivity to this component (Kahn et al., 2010).

\section{Results}

\subsection{East Asia}

Rapid increases in emissions of aerosols and their precursors in East Asia are causing growing concern because of the broad impact they have on aerosol loading over the North Pacific and mainland North America, especially the United States (Yu et al., 2008). Figure 2 compares climatological AODs from spherical nonabsorbing aerosols for July retrieved by MISR in East Asia with the sulfate AOD predicted by GOCART and SPRINTARS. Figure $2 a$ and $b$ are the respective MISR nonabsorbing and GOCART sulfate AOD maps averaged over 8 years, and Fig. $2 \mathrm{c}$ is the sulfate AOD in SPRINTARS for the beginning of July 2006. 
Table 1. Combination of AOD by components for comparison of MISR with the GOCART and SPRINTARS models. The names of aerosol components in MISR are from Table 1 in Kahn et al. (2015).

\begin{tabular}{lll}
\hline MISR & GOCART & SPRINTARS \\
\hline $\begin{array}{l}\text { weakly + strongly spherical absorbing aerosols } \\
\text { :sph_absorb_0.12_ssa_green_09 } \\
+ \text { sph_absorb_0.12_ssa_green_08 }\end{array}$ & $\begin{array}{l}\text { black carbon } \\
+ \text { organic aerosols }\end{array}$ & carbonaceous aerosols \\
\hline medium + coarse nonspherical aerosols & & \\
: medium_grains + coarse_spheroids & dust & dust \\
\hline $\begin{array}{l}\text { very small+ small + medium spherical nonabsorbing aerosols } \\
\text { : sph_nonabsorb_0.06 }\end{array}$ & sulfate \\
+ sph_nonabsorb_0.12 & & sulfate \\
+ sph_nonabsorb_0.26 & & \\
\hline
\end{tabular}

The three maps of nonabsorbing AOD are displayed using the same color scale. Peak AOD values correspond to source regions in the Shandong province south of Beijing and are closely related to the emissions in this heavily industrial region (Streets et al., 2007). The spatial gradient in AOD is due to transport and deposition processes. In spite of the differences in time period between SPRINTARS and the other two data sets, Fig. 2a-c show good qualitative agreement in their representation of the spatial distribution of spherical nonabsorbing/sulfate AOD. The reason for the generally good agreement is likely that the industrial source regions are well considered in the emission database used for GOCART and SPRINTARS, and at least at this level of detail, interannual variability does not alias the SPRINTARS result.

Figure $2 \mathrm{~d}$ and e show the probability mass function (PMF) of the nonabsorbing AOD and total AOD, corresponding to the white boxes on the maps in Fig. 2a-c. The white boxes capture the region of highest AOD loading. The daily AOD observations from the AERONET station at Shouxian $\left(116.8^{\circ} \mathrm{E}, 32.6^{\circ} \mathrm{N}\right)$, inside the white box, is available only in 2008. The PMF is simply the histogram scaled so that the total area of the bars corresponds to some fixed value. It is important to recognize that Fig. 2d and e from MISR and GOCART include both temporal and spatial variability, because data for the histograms are aggregated over an 8-year time period, whereas Fig. 2d and e from SPRINTARS represent primarily spatial variability, and Fig. 2e from AERONET represents primarily temporal variability. Even so, the nonabsorbing particle histograms have similar overall shapes, with similar standard deviations ( 0.39 for MISR, 0.33 for GOCART, and 0.33 for SPRINTARS), but considerable differences in the peak magnitudes and the mean nonabsorbing/sulfate AOD values ( 0.40 for MISR, 0.53 for GOCART, and 0.36 for SPRINTARS). It is also noticeable that the shapes of the distributions are non-Gaussian, with long positive tails. The ability to visualize the full AOD distribution is an important analysis technique enabled by the MISR JOINT_AS product. The skewness of the MISR distribution is 1.70 and for GOCART and SPRINTARS, the skewness values are 0.93 and 2.6 respectively, showing that the GOCART model has smaller positive skewness corresponding to more high AOD values between 0.5 and 1.5 than MISR, whereas SPRINTARS is more peaked toward the lower values. These features in the distributions are not clearly visible when comparing climatological mean AOD spatial maps in Fig. $2 \mathrm{a}-\mathrm{c}$.

Levy et al. (2009) describe how the monthly mean AOD reported by satellite instruments is highly dependent on the averaging method selected. Reliance on the mean and standard deviation alone is particularly problematic when large outliers are common. A satellite instrument can miss extreme events due to its sampling characteristics (Colarco et al., 2014), but these events may be captured by a model with better temporal and complete spatial sampling. If this is the case, the mean AOD values could be very different, but, as shown here, the distributions are still similar.

Compared to the distributions of nonabsorbing AOD in Fig. 2d, there are significant differences in the total AOD distributions across the observations and models. The secondary peak around AOD 1.5 only appears in the AERONET AOD data. MISR's total AOD observations show a multimodal distribution similar to AERONET, but still the differences between MISR and AERONET are large, and of course, the temporal and spatial sampling of the two are quite different. Unlike the observations, the total AOD distributions for the two models are positively skewed and unimodal. When the distributions have multiple modes, we should not read too much into averaged AOD for comparison between observations and models.

It is worth noting that taking the base-10 logarithm of the nonabsorbing/sulfate AODs in Fig. 2d results in distributions with skewnesses of -0.21 (MISR), -0.41 (GOCART), and -0.11 (SPRINTARS). These skewness values are close to zero, indicating that these modified distributions are nearly log-normal, as is typical for atmospheric pollutant concentrations (Ott, 1990). The results in Fig. 2 as a whole indicate that combining MISR spherical nonabsorbing AOD in 


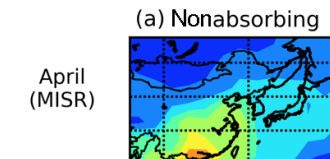

(e) Sulfate

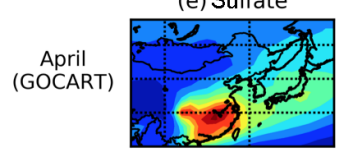

(i) Nonabsorbing

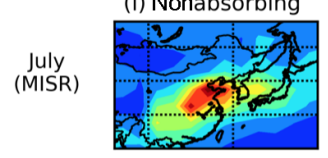

(m) Sulfate

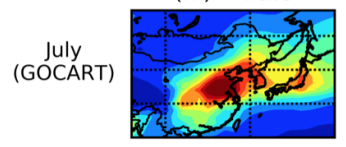

(q) Sulfate

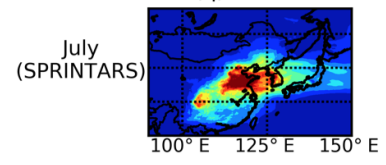

(b) Nonspherical

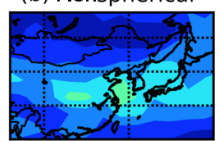

(f) Dust

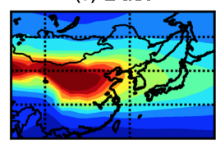

(j) Nonspherical

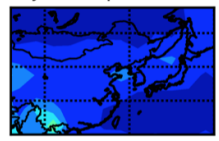

(n) Dust

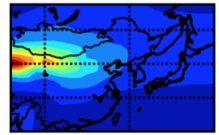

(r) Dust

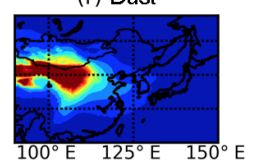

(c) Absorbing

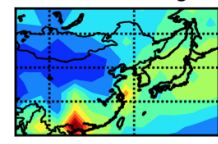

(g) Carbonaceous

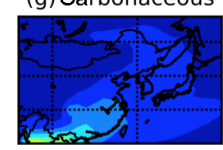

(k) Absorbing

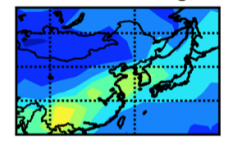

(o) Carbonaceous

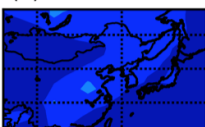

(s) Carbonaceous

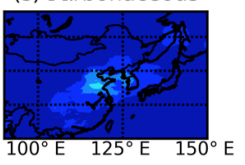

(d) Total

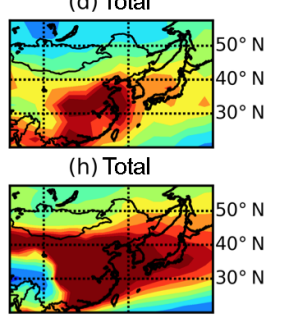

(I) Total

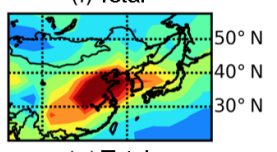

(p) Total

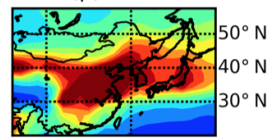

(t) Total

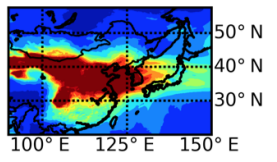

0.0

0.1

0.2

0.3

0.4

0.5

Figure 3. Maps of average MISR optical depth of spherical nonabsorbing aerosols, nonspherical, spherical absorbing aerosols, and total aerosols in April (a-d) and July (i-l). Maps of average GOCART optical depth of sulfate, dust, carbonaceous, and total aerosols in April (eh) and July (m-p). Maps of average SPRINTARS optical depth of sulfate, dust, carbonaceous, and total aerosols in July (q-t).

the manner described appears to be a good proxy for sulfate aerosol loading, at least in July in East Asia.

When comparing satellite-derived total column AOD with modeled AOD, it is common practice to assume that a single, dominant aerosol type accounts for the majority of the modeled AOD in a region (e.g., Kim et al., 2007). However, this approach will not work if the dominant pollutant type varies over time (Wang et al., 2010). Another useful characteristic of the MISR operational aerosol retrieval is that the mixture climatology is applied globally to all locations and seasons, unlike MODIS over land, which relies on aerosol models that change as a function of location and season based on AERONET climatology (Levy et al., 2013). A recent study by Eck et al. (2013), for example, shows that the seasonality in biomass-burning SSA in southern Africa is better captured by MISR than MODIS due to the algorithm flexibility in choosing mixtures, combined with the additional information content of the multi-angle measurements (e.g., Kahn and Gaitley, 2015). Figure 3 shows the monthly partitioning of aerosol type from MISR, GOCART, and SPRINTARS, based on the 8-year climatology from MISR and GOCART and the 8 -day average from SPRINTARS. This comparison is possible because the MISR JOINT_AS product retains statistical information on the full range of passing particle types within a $5^{\circ} \times 5^{\circ}$ grid cell instead of reporting a single, dominant particle type.
What is immediately apparent when comparing the April and July particle type climatologies from MISR and GOCART is that the dominant source region in April is located in the vicinity of Hong Kong, whereas in July it is farther to the north as discussed in relation to Fig. 2. In April, the southern source region is dominated by nonabsorbing aerosols (sulfate and possibly nitrate), with absorbing aerosols being a secondary contributor. Both the partitioning and seasonality are consistent with monthly observations of $\mathrm{PM}_{2.5}$ constituents in Hong Kong (Haung et al., 2014). Additionally, there are significantly more nonspherical aerosols in the region in April, when dust storms are most frequent (e.g., Wang et al., 2010; Lee et al., 2013). Although individual dust events do not last very long, they are captured in the longterm MISR climatology due to their seasonal recurrence. The dust makes an important contribution to the total AOD especially in April, but it would be a mistake to use the total monthly mean AOD in the region to study the transport and radiative effects of dust by itself in China. The dust AOD in GOCART and SPRINTARS is higher than MISR nonspherical AOD in July and especially in April. Sulfate AOD in SPRINTARS for July shows qualitative good agreement with MISR and GOCART, but the sulfate AOD in the models is higher than MISR spherical nonabsorbing AOD in both months. Figure 3 demonstrates the value of aerosol data from the MISR JOINT_AS product to further study climate im- 
pacts and air quality issues due to aerosols over East Asia together with chemistry model simulations.

\subsection{Eastern Atlantic}

The eastern Atlantic Ocean in July is directly downwind from the largest source of dust aerosols on Earth (e.g., Koven and Fung, 2008; Ridley et al., 2012). Figure 4a shows a map of the climatology of nonspherical aerosol optical depth for July from 8 years of MISR data from the JOINT_AS product for the eastern Atlantic off western Africa. Figure $4 \mathrm{~b}$ and c show the dust aerosol AOD simulated by GOCART and SPRINTARS respectively for the same region. We focus on retrievals over ocean because of the highly episodic nature of dust events (e.g., Ben-Ami et al., 2012) (see also Fig. 5), which make direct comparisons difficult in the source regions themselves due to sampling differences. In addition, although MISR-reported AODs show good agreement with AERONET over ocean, downwind of the source region, the magnitude tends to be underestimated in situations with high aerosol loading, as in the case of large dust outbreaks, especially near-source (Kahn et al., 2010; Carboni et al., 2012; Banks et al., 2013). On the modeling side, in the first AEROCOM intercomparison, the SPRINTARS model also tends to underestimate the emissions in north Africa, with dust particles having too short a lifetime (1.6 days) (Huneeus et al., 2011). In this regard, it is important to recall that the MISR and GOCART data represent temporal averages over 8 years, whereas the SPRINTARS model would capture background dust levels, and possibly a single, large dust event. The two models, especially GOCART, show much higher dust AOD over land than the MISR Version 22 product. In spite of these differences, there is general agreement among the spatial patterns of the Fig. 4a-c maps. The latitudinal and longitudinal spread is less in SPRINTARS than in the MISR and GOCART climatologies. Between the end of March and mid-October, the location of the maximum dust emission shifts with time, consistent with the differences shown here in the latitudinal distributions (Prospero et al., 2002; BenAmi et al., 2012). The difference in longitudinal extent could be related to the difference in the dust particle lifetime in the SPRINTARS (Huneeus et al., 2011) and GOCART models.

Focusing on the white rectangles on the maps, Fig. $4 \mathrm{~d}$ and e show the PMFs of the nonspherical (dust) AOD and total AOD from MISR and the models. GOCART shows the largest mean dust AOD of 0.51, followed by MISR (0.41) and SPRINTARS (0.33). The three distributions have similar standard deviations ( 0.23 for MISR, 0.22 for GOCART, and 0.20 for SPRINTARS). The distributions also commonly have significant positive skewness ( 0.88 for MISR, 0.63 for GOCART, and 1.40 for SPRINTARS), with the SPRINTARS model showing greater skewness than the satellite observations. Looking at the distributions themselves, it is apparent that both nonspherical and total AOD in the region are much better behaved than the AOD distribution in East Asia, which contains multiple modes in the observed total AOD distributions. Although the peaks of the three distributions in Fig. $4 \mathrm{~d}$ are nearly identical (around 0.4), the SPRINTARS distribution is more skewed than MISR and GOCART. The relatively small positive skewness in MISR and GOCART may be due to sampling over the longer 8-year period. Careful inspection of the three distributions shows that frequency of AOD values larger than the highest peak in the SPRINTARS model falls more rapidly than it does in the MISR observations and GOCART model, another indication that the dust lifetime may be too short in SPRINTARS. Again, this demonstrates the importance of comparing probability distributions in AOD between models and observations rather than relying only on differences in mean AODs as a model performance metric. The July total AOD observations from the AERONET site at Cabo Verde $\left(22.9^{\circ} \mathrm{W}, 16.7^{\circ} \mathrm{N}\right)$ is available only for 2005 , so the green histogram in Fig. $4 \mathrm{e}$ is based on the data for a single month.

Figure 5 shows the nonspherical AOD for north Africa for July for 2000 to 2014 from the MISR JOINT_AS product at $5^{\circ} \times 5^{\circ}$ resolution. The significant interannual variability in both dust loading and peak locations is immediately apparent. The western Sahara is particularly variable in both location and intensity, but the region downwind from the Bodélé Depression in Chad (Bristow et al., 2009), around $10^{\circ} \mathrm{E}$, is persistent, although with varying intensity from year to year. This indicates that in north Africa, the stationarity assumption for the spatial distribution of nonspherical AOD does not work well. Therefore, if simulation data sets are available for a longer period, it is important to compare simulated dust AOD over the region using observational data sets with enough temporal overlap with the simulation.

\subsection{Central Africa}

Over half of the global emissions of carbon comes from Africa (van der Werf et al., 2010) and in central Africa, south of the equator, these emissions are dominated by savanna and grassland fires (Ichoku and Ellison, 2014). Figure 6a shows the MISR absorbing aerosol climatology for July from 8 years of data from the JOINT_AS product. Figure $6 \mathrm{~b}$ exhibits the sum of two optical depths, black carbon, and organic aerosols in July from GOCART, averaged over 8 years. Figure $6 \mathrm{c}$ shows the carbonaceous aerosols from the SPRINTARS model from 1 July through 8 July 2006. The agreement between the satellite observations and the models appears to be qualitatively good. Careful examination shows that the highest aerosol loading predicted by the models occurs primarily over northwestern Angola and the Democratic Republic of the Congo, whereas the satellite data have a maximum extending from the Democratic Republic of the Congo, across the Republic of the Congo, into the Atlantic Ocean. The modeled carbonaceous aerosols are therefore displaced to the southeast relative to the MISR satellite observations. A similar displacement was found by 

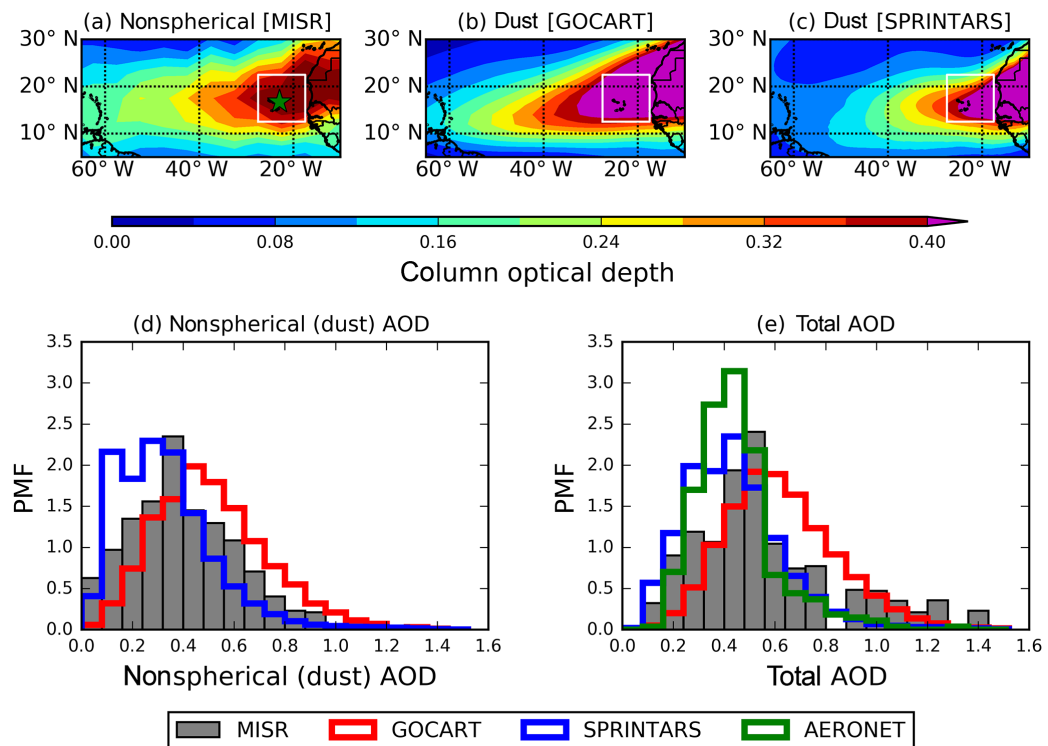

Figure 4. (a) Climatological mean optical depth of the nonspherical aerosols in MISR, dust AOD in (b) GOCART, and (c) SPRINTARS over the eastern Atlantic for July. Data from the eight Julys between 2000 and 2007 are averaged for MISR and GOCART. Spatiotemporal distributions of (d) the nonspherical (or dust) AOD and (e) total AOD from MISR (gray bars), from GOCART (red lines), and from SPRINTARS (blue lines), covering the boxed region $\left(112.5-122.5^{\circ} \mathrm{E}, 32.5-37.5^{\circ} \mathrm{N}\right.$ ) off the coast are displayed. The green star in (a) displays a location of the AERONET station in Cabo Verde. The green line in (e) represents the total AOD distribution in Cabo Verde for July 2005.

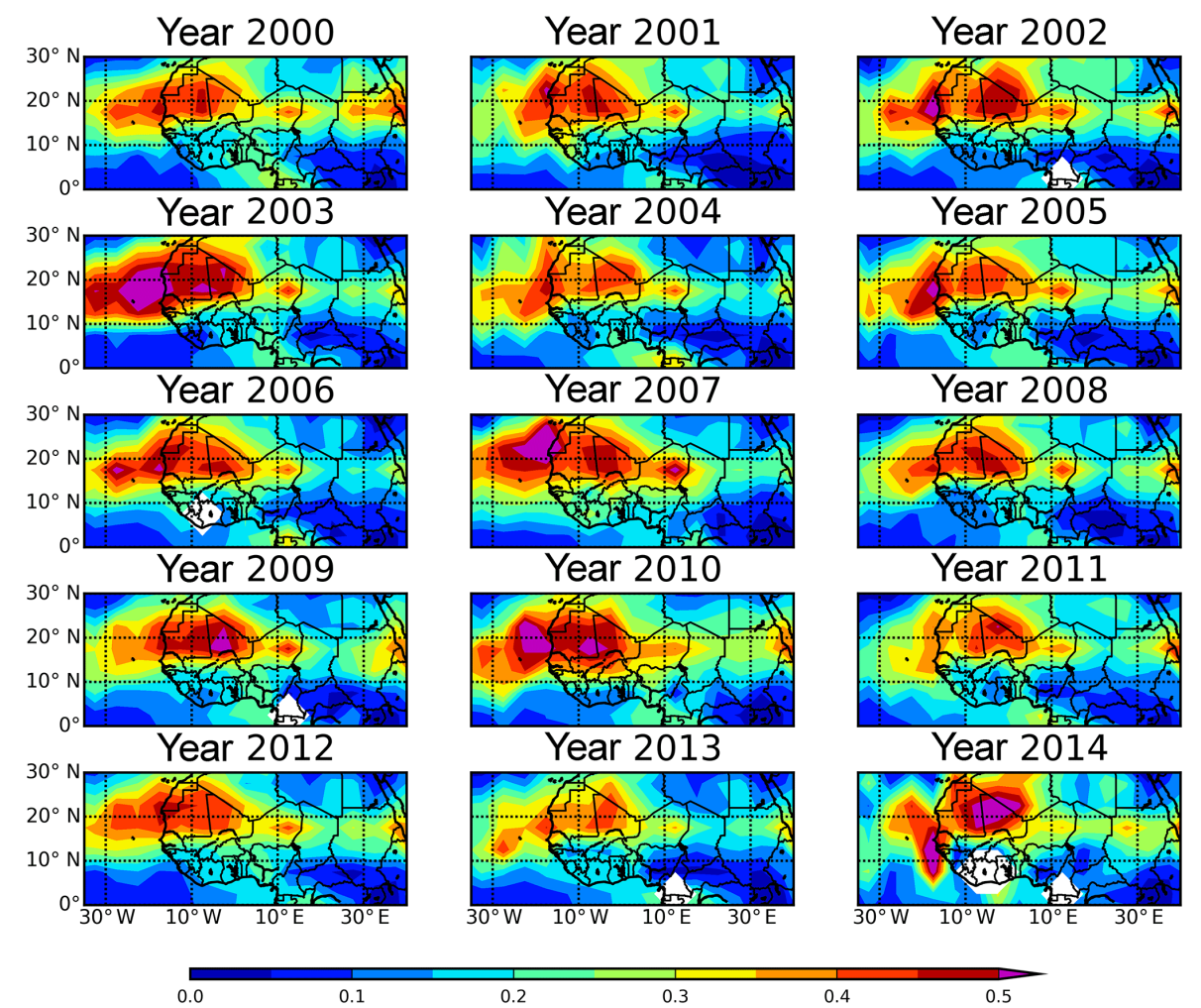

Figure 5. Monthly mean optical depth of the nonspherical aerosols from MISR in July for 15 years between 2000 and 2014 . The white blank spots indicate that there were no retrieved nonspherical AOD values for the month. 

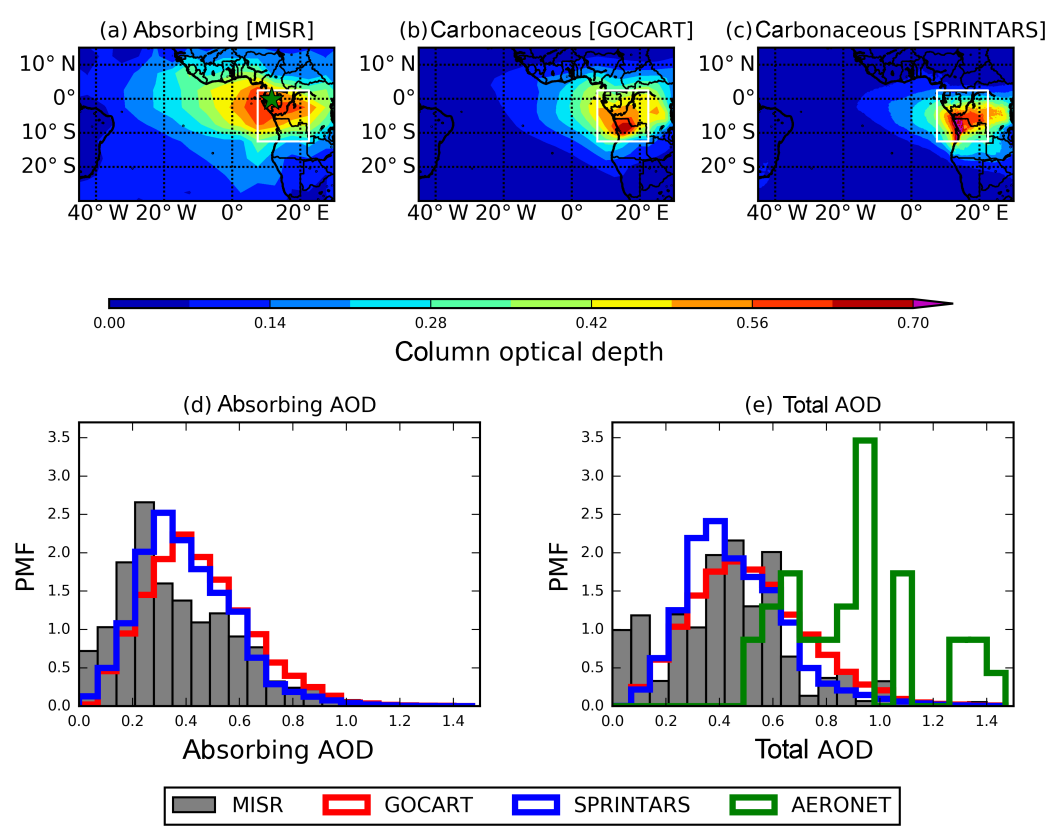

Figure 6. (a) Climatological mean optical depth of the spherical absorbing aerosols in MISR, dust AOD in (b) GOCART and (c) SPRINTARS over West Africa for July. Data from the eight Julys between 2000 and 2007 are averaged for MISR and GOCART. Spatiotemporal distributions of (d) the absorbing (or carbonaceous) AOD and (e) total AOD from MISR (gray bars), from GOCART (red lines), and from SPRINTARS (blue lines), covering the boxed emission source region $\left(7.5-22.5^{\circ} \mathrm{E}, 12.5^{\circ} \mathrm{S}-2.5^{\circ} \mathrm{N}\right)$ are displayed. The green star in $(\mathbf{a})$ displays a location of the AERONET station in Lopé National Park. The green line in (e) represents the total AOD distribution in Lopé National Park for July 2014.

Liousse et al. (2010) when comparing POLDER total column AOD measurements from the PARASOL satellite with modeled AOD for July 2006. These authors attribute the displacement to errors in the location of the biomass-burning emissions, errors in transport, or errors in the satellite products. In fact, the location of the maximum carbonaceous AOD in SPRINTARS corresponds well with the location of the maximum black carbon emission in the Global Emissions Inventory Activities (GEIA) emissions (Liousse et al., 2010), which are used in the SPRINTARS model (Takemura et al., 2005). The GEIA emissions distribution in this region is consistent with version 3 of the Global Fire Emissions Database (GFED3) (van der Werf et al., 2010) as well as the Fire Energetics and Emissions Research version 1.0 (FEER.v1) (Ichoku and Ellison, 2014) database. The spatial distribution of absorbing aerosols from MISR shown in Fig. 6a is also consistent with the AOD map from POLDER shown in Liousse et al. (2010), even though the PARASOL satellite has a 13:30 LT (local time) equatorial crossing time compared to the 10:30 LT equatorial crossing time for the Terra satellite. These results implicate the transport and deposition processes in the GOCART and SPRINTARS models, rather than the emissions inventory or the satellite products, themselves. Even so, recent work by Marlier et al. (2014) has shown that daily fire emissions lead to different model results compared to monthly fire emissions, and Veira et al. (2015) show that the injection height of aerosols can also play a role in the modeled distribution of AOD from biomass burning. The paper by Matichuk et al. (2007) includes a longer list of additional model sensitivities that complicate model predictions of carbonaceous aerosol loading, particularly in transport regions.

Figure $6 \mathrm{~d}$ and e show the distributions of spherical absorbing/carbonaceous AOD and total AOD from MISR, the two models, and AERONET for the white boxes on the maps in Fig. $6 a, b$, and c, which corresponds to the region of highest AOD loading in both the observations and the models. In this case, the two distributions from the models are quite similar. The mean MISR absorbing-particle AOD is 0.36, and the means for GOCART and SPRINTARS carbonaceous AOD are 0.45 and 0.40 , with the difference between MISR and the models likely due to the higher AOD near the source regions, and possibly the lack of absorbing-particle optical models in the MISR climatology covering the natural range of size distributions and SSA values (Kahn et al., 2010). The peak values in the models are also slightly higher than MISR. The standard deviations for MISR, GOCART, and SPRINTARS are $0.22,0.19$, and 0.18 , respectively, with the MISR distribution skewed slightly higher with a skewness of 0.77 , compared to 0.67 for GOCART and 0.71 for SPRINTARS. These results are consistent with the models producing carbonaceous aerosols that are not transported as far as the MISR observations indicate. The Lopé National Park AERONET site in Gabon provides the only available 
surface-based total AOD observations in the study region for July 2014. The AERONET site reported anomalously high AOD with mean of 0.91. Due to the limited temporal coverage of the AERONET observations, MISR's total AOD data over a longer period are much more useful for comparing with simulated total AOD. Again, the ability to generate distributions of AOD by aerosol type and total AOD is an important strength of the MISR JOINT_AS product and, as shown in this example, provides a powerful model diagnostic.

\section{Conclusions}

Although a number of previous studies have evaluated aerosols modeled in both GCMs and chemistry models using observational data sets from a variety of sources, studies focusing on specific aerosol types have been limited by the lack of global comparison data sets. However, it is well understood that model improvements depend on moving beyond simple comparisons of total AOD. In this work, we describe the MISR Level 3 Joint Aerosol product that provides monthly climatological distributions of AOD for eight different aerosol components, which allows detailed statistical comparisons between satellite observations and models. In addition, we demonstrate how the MISR components can be combined into analogs for model aerosol species. In comparisons with two chemistry transport models, GOCART and SPRINTARS, we show that reliance on the simple mean and standard deviation of the AOD distribution can result in misleading conclusions when evaluating simulated AOD against observed AOD. In the three high-AOD regions studied, high positive skewness in the component-AOD distributions is indicative of large outliers that may be due to episodic events or differences in sampling that must be considered when making comparisons between satellite observations and model data sets. We also show how the reliance on a single, dominant aerosol type can be inappropriate for certain locations and seasons.

We believe that the comparison of AOD distributions by components between MISR and chemistry models will provide useful guidance to improve computations of aerosolrelated radiative forcing in the models. Given that models reasonably represent transport processes and chemical reactions associated with aerosols, MISR AOD by components can provide a constraint on the strength of emissions (e.g., Petrenko et al., 2012) and lifetime of aerosols. The first step should be matching simulated AOD by components with those from MISR by adjusting emissions and lifetime of aerosols in models. Further research along these lines would clarify uncertainties of chemistry models on regional and global scales. Conversely, scrutinizing the AOD distributions reported by MISR using chemistry climate models may feed back and improve the quality of aerosol retrievals from MISR.
Acknowledgements. This work was performed at the Jet Propulsion Laboratory, California Institute of Technology, under contract with NASA. We thank the MISR team for providing facilities and useful discussions. K. Suzuki was supported by the Environment Research and Technology Development Fund (S-12) of the Ministry of the Environment, Japan, and by funds from JAXA/EarthCARE and GCOM-C projects. The work of Ralph A. Kahn is supported in part by NASA's Climate and Radiation Research and Analysis Program under H. Maring, NASA's Atmospheric Composition Program under R. Eckman, and the NASA Earth Observing System MISR instrument project.

Edited by: A. Sorooshian

\section{References}

Banks, J. R., Brindley, H. E., Flamant, C., Garay, M. J., Hsu, N. C., Kalashnikova, O. V., Klüser, L., and Sayer, A. M.: Intercomparison of satellite dust retrieval products over the west African Sahara during the Fennec campaign in June 2011, Remote Sens. Environ., 136, 99-116, doi:10.1016/j.rse.2013.05.003, 2013.

Bellouin, N., Jones, A., Haywood, J., and Christopher, S. A.: Updated estimate of aerosol direct radiative forcing from satellite observations and comparison against the Hadley Centre climate model, J. Geophys. Res.-Atmos., 113, D10205, doi:10.1029/2007jd009385, 2008.

Bellouin, N., Quaas, J., Morcrette, J.-J., and Boucher, O.: Estimates of aerosol radiative forcing from the MACC re-analysis, Atmos. Chem. Phys., 13, 2045-2062, doi:10.5194/acp-13-20452013, 2013.

Ben-Ami, Y., Koren, I., Altaratz, O., Kostinski, A., and Lehahn, Y.: Discernible rhythm in the spatio/temporal distributions of transatlantic dust, Atmos. Chem. Phys., 12, 2253-2262, doi:10.5194/acp-12-2253-2012, 2012.

Boucher, O., Randall, D., Artaxo, P., Bretherton, C., Feingold, G., Forster, P., Kerminen, V.-M., Kondo, Y., Liao, H., Lohmann, U., Rasch, P., Satheesh, S., Sherwood, S., Stevens, B., and Zhang, X.: Clouds and Aerosols, book Sect. 7, 571-658, Cambridge University Press, Cambridge, United Kingdom and New York, NY, USA, doi:10.1017/CBO9781107415324.016, 2013.

Braverman, A.: Compressing massive geophysical datasets using vector quantization, J. Comput. Graph. Stat., 11, 44-62, doi:10.1198/106186002317375613, 2002.

Braverman, A. and Di Girolamo, L.: MISR global data products: A new approach, IEEE T. Geosci. Remote Sens., 40, 1626-1636, 2002.

Bristow, C. S., Drake, N., and Armitage, S.: Deflation in the dustiest place on Earth: The Bodélé Depression, Chad, Geomorphology, 105, 50-58, doi:10.1016/j.geomorph.2007.12.014, 2009.

Carboni, E., Thomas, G. E., Sayer, A. M., Siddans, R., Poulsen, C. A., Grainger, R. G., Ahn, C., Antoine, D., Bevan, S., Braak, R., Brindley, H., DeSouza-Machado, S., Deuzé, J. L., Diner, D., Ducos, F., Grey, W., Hsu, C., Kalashnikova, O. V., Kahn, R., North, P. R. J., Salustro, C., Smith, A., Tanré, D., Torres, O., and Veihelmann, B.: Intercomparison of desert dust optical depth from satellite measurements, Atmos. Meas. Tech., 5, 1973-2002, doi:10.5194/amt-5-1973-2012, 2012. 
Chin, M., Ginoux, P., Kinne, S., Torres, O., Holben, B. N., Duncan, B. N., Martin, R. V., Logan, J. A., Higurashi, A., and Nakajima, T.: Tropospheric aerosol optical thickness from the GOCART model and comparisons with satellite and Sun photometer measurements, J. Atmos. Sci., 59, 461-483, doi:10.1175/15200469(2002)059<0461:Taotft>2.0.Co;2, 2002.

Chin, M., Diehl, T., Tan, Q., Prospero, J. M., Kahn, R. A., Remer, L. A., Yu, H., Sayer, A. M., Bian, H., Geogdzhayev, I. V., Holben, B. N., Howell, S. G., Huebert, B. J., Hsu, N. C., Kim, D., Kucsera, T. L., Levy, R. C., Mishchenko, M. I., Pan, X., Quinn, P. K., Schuster, G. L., Streets, D. G., Strode, S. A., Torres, O., and Zhao, X.-P.: Multi-decadal aerosol variations from 1980 to 2009: a perspective from observations and a global model, Atmos. Chem. Phys., 14, 3657-3690, doi:10.5194/acp-14-3657-2014, 2014.

Colarco, P. R., Kahn, R. A., Remer, L. A., and Levy, R. C.: Impact of satellite viewing-swath width on global and regional aerosol optical thickness statistics and trends, Atmos. Meas. Tech., 7, 2313-2335, doi:10.5194/amt-7-2313-2014, 2014.

Diehl, T., Heil, A., Chin, M., Pan, X., Streets, D., Schultz, M., and Kinne, S.: Anthropogenic, biomass burning, and volcanic emissions of black carbon, organic carbon, and $\mathrm{SO}_{2}$ from 1980 to 2010 for hindcast model experiments, Atmos. Chem. Phys. Discuss., 12, 24895-24954, doi:10.5194/acpd-12-24895-2012, 2012.

Diner, D. J., Braswell, B. H., Davies, R., Gobron, N., Hu, J., Jim, Y., Kahn, R. A., Knyazikhin, Y., Loeb, N., Muller, J.P., Nolin, A. W., Pinty, B., Schaaf, C. B., Seiz, G., and Stroeve, J.: The value of multiangle measurements for retrieving structurally and radiatively consistent properties of clouds, aerosols, and surfaces, Remote Sens. Environ., 97, 495-518, doi:10.1016/j.rse.2005.06.006, 2005a.

Diner, D. J., Martonchik, J. V., Kahn, R. A., Pinty, B., Gobron, N., Nelson, D. L., and Holben, B. N.: Using angular and spectral shape similarity constraints to improve MISR aerosol and surface retrievals over land, Remote Sens. Environ., 94, 155-171, doi:10.1016/j.rse.2004.09.009, 2005b.

Eck, T. F., Holben, B. N., Reid, J. S., Mukelabai, M. M., Piketh, S. J., Torres, O., Jethva, H. T., Hyer, E. J., Ward, D. E., Dubovik, O., Sinyuk, A., Schafer, J. S., Giles, D. M., Sorokin, M., Smirnov, A., and Slutsker, I.: A seasonal trend of single-scattering albedo in southern African biomass-burning particles: Implications for satellite products and estimates of emissions for the world's largest biomass-burning source, J. Geophys. Res.-Atmos., 118, 6414-6432, doi:10.1002/jgrd.50500, 2013.

Ganor, E., Osetinsky, I., Stupp, A., and Alpert, P.: Increasing trend of African dust, over 49 years, in the eastern Mediterranean, J. Geophys. Res., 115, D07201, doi:10.1029/2009jd012500, 2010.

Haung, X. H. H., Bian, Q., Ng, W. M., Louie, P. K. K., and $\mathrm{Yu}, \mathrm{J}$. Z.: Characterization of $\mathrm{PM}_{2.5}$ major components and source investigation in suburban Hong Kong: A one year monitoring study, Aerosol Air Qual. Res., 14, 237-250, doi:10.4209/aaqr.2013.01.0020, 2014.

Higurashi, A. and Nakajima, T.: Detection of aerosol types over the East China Sea near Japan from four-channel satellite data, Geophys. Res. Lett., 29, 17-1-17-4, doi:10.1029/2002GL015357, 2002

Holben, B. N., Eck, T. F., Slutsker, I., Tanre, D., Buis, J. P., Setzer, A., Vermote, E., Reagan, J. A., Kaufman, Y. J., Nakajima, T., Lavenu, F., Jankowiak, I., and Smirnov, A.: AERONET - A fed- erated instrument network and data archive for aerosol characterization, Remote Sens. Environ., 66, 1-16, doi:10.1016/S00344257(98)00031-5, 1998.

Holzer-Popp, T., Schroedter-Homscheidt, M., Breitkreuz, H., Martynenko, D., and Klüser, L.: Improvements of synergetic aerosol retrieval for ENVISAT, Atmos. Chem. Phys., 8, 7651-7672, doi:10.5194/acp-8-7651-2008, 2008.

Huneeus, N., Schulz, M., Balkanski, Y., Griesfeller, J., Prospero, J., Kinne, S., Bauer, S., Boucher, O., Chin, M., Dentener, F., Diehl, T., Easter, R., Fillmore, D., Ghan, S., Ginoux, P., Grini, A., Horowitz, L., Koch, D., Krol, M. C., Landing, W., Liu, X., Mahowald, N., Miller, R., Morcrette, J.-J., Myhre, G., Penner, J., Perlwitz, J., Stier, P., Takemura, T., and Zender, C. S.: Global dust model intercomparison in AeroCom phase I, Atmos. Chem. Phys., 11, 7781-7816, doi:10.5194/acp-11-7781-2011, 2011.

Ichoku, C. and Ellison, L.: Global top-down smoke-aerosol emissions estimation using satellite fire radiative power measurements, Atmos. Chem. Phys., 14, 6643-6667, doi:10.5194/acp14-6643-2014, 2014.

IPCC: Climate Change 2013: The Physical Science Basis. Contribution of Working Group I to the Fifth Assessment Report of the Intergovernmental Panel on Climate Change, Cambridge University Press, Cambridge, United Kingdom and New York, NY, USA, doi:10.1017/CBO9781107415324, 2013.

Kahn, R., Banerjee, P., and McDonald, D.: Sensitivity of multiangle imaging to natural mixtures of aerosols over ocean, J. Geophys. Res., 106, 18219, doi:10.1029/2000jd900497, 2001.

Kahn, R. A. and Gaitley, B. J.: An analysis of global aerosol type as retrieved by MISR, J. Geophys. Res.-Atmos., 120, 4248-4281, doi:10.1002/2015jd023322, 2015.

Kahn, R. A., Nelson, D. L., Garay, M. J., Levy, R. C., Bull, M. A., Diner, D. J., Martonchik, J. V., Paradise, S. R., Hansen, E. G., and Remer, L. A.: MISR aerosol product attributes and statistical comparisons with MODIS, IEEE T. Geosci. Remote Sens., 47, 4095-4114, doi:10.1109/TGRS.2009.2023115, 2009.

Kahn, R. A., Gaitley, B. J., Garay, M. J., Diner, D. J., Eck, T. F., Smirnov, A., and Holben, B. N.: Multiangle Imaging SpectroRadiometer global aerosol product assessment by comparison with the Aerosol Robotic Network, J. Geophys. Res.-Atmos., 115, D23209, doi:10.1029/2010jd014601, 2010.

Kalashnikova, O. V., Kahn, R., Sokolik, I. N., and Li, W. H.: Ability of multiangle remote sensing observations to identify and distinguish mineral dust types: Optical models and retrievals of optically thick plumes, J. Geophys. Res.-Atmos., 110, D18s14, doi:10.1029/2004jd004550, 2005.

Kim, J., Lee, J., Lee, H. C., Higurashi, A., Takemura, T., and Song, C. H.: Consistency of the aerosol type classification from satellite remote sensing during the Atmospheric Brown Cloud-East Asia Regional Experiment campaign, J. Geophys. Res.-Atmos., 112, D22S33, doi:10.1029/2006jd008201, 2007.

Koven, C. D. and Fung, I.: Identifying global dust source areas using high-resolution land surface form, J. Geophys. Res., 113, D22204, doi:10.1029/2008JD010195, 2008.

Lamarque, J.-F., Shindell, D. T., Josse, B., Young, P. J., Cionni, I., Eyring, V., Bergmann, D., Cameron-Smith, P., Collins, W. J., Doherty, R., Dalsoren, S., Faluvegi, G., Folberth, G., Ghan, S. J., Horowitz, L. W., Lee, Y. H., MacKenzie, I. A., Nagashima, T., Naik, V., Plummer, D., Righi, M., Rumbold, S. T., Schulz, M., Skeie, R. B., Stevenson, D. S., Strode, S., Sudo, K., Szopa, S., 
Voulgarakis, A., and Zeng, G.: The Atmospheric Chemistry and Climate Model Intercomparison Project (ACCMIP): overview and description of models, simulations and climate diagnostics, Geosci. Model Dev., 6, 179-206, doi:10.5194/gmd-6-179-2013, 2013.

Lee, H., Kim, H., Honda, Y., Lim, Y. H., and Yi, S.: Effect of Asian dust storms on daily mortality in seven metropolitan cities of Korea, Atmos. Environ., 79, 510-517, doi:10.1016/j.atmosenv.2013.06.046, 2013.

Levy, R. C., Leptoukh, G. G., Kahn, R., Zubko, V., Gopalan, A., and Remer, L. A.: A Critical Look at Deriving Monthly Aerosol Optical Depth From Satellite Data, IEEE T. Geosci. Remote Sens., 47, 2942-2956, doi:10.1109/Tgrs.2009.2013842, 2009.

Levy, R. C., Mattoo, S., Munchak, L. A., Remer, L. A., Sayer, A. M., Patadia, F., and Hsu, N. C.: The Collection 6 MODIS aerosol products over land and ocean, Atmos. Meas. Tech., 6, 29893034, doi:10.5194/amt-6-2989-2013, 2013.

Li, G. H., Wang, Y., Lee, K. H., Diao, Y. W., and Zhang, R. Y.: Increased winter precipitation over the North Pacific from 1984-1994 to 1995-2005 inferred from the Global Precipitation Climatology Project, Geophys. Res. Lett., 35, L13821, doi:10.1029/2008g1034668, 2008.

Li, S., Garay, M. J., Chen, L., Rees, E., and Liu, Y.: Comparison of GEOS-Chem aerosol optical depth with AERONET and MISR data over the contiguous United States, J. Geophys. Res.-Atmos., 118, 11228-11241, doi:10.1002/jgrd.50867, 2013.

Li, S., Kahn, R., Chin, M., Garay, M. J., and Liu, Y.: Improving satellite-retrieved aerosol microphysical properties using GOCART data, Atmos. Meas. Tech., 8, 1157-1171, doi:10.5194/amt-8-1157-2015, 2015.

Liousse, C., Guillaume, B., Grégoire, J. M., Mallet, M., Galy, C., Pont, V., Akpo, A., Bedou, M., Castéra, P., Dungall, L., Gardrat, E., Granier, C., Konaré, A., Malavelle, F., Mariscal, A., Mieville, A., Rosset, R., Serça, D., Solmon, F., Tummon, F., Assamoi, E., Yoboué, V., and Van Velthoven, P.: Updated African biomass burning emission inventories in the framework of the AMMAIDAF program, with an evaluation of combustion aerosols, Atmos. Chem. Phys., 10, 9631-9646, doi:10.5194/acp-10-96312010, 2010.

Liu, S., Aiken, A. C., Arata, C., Dubey, M. K., Stockwell, C. E., Yokelson, R. J., Stone, E. A., Jayarathne, T., Robinson, A. L., DeMott, P. J., and Kreidenweis, S. M.: Aerosol single scattering albedo dependence on biomass combustion efficiency: Laboratory and field studies, Geophys. Res. Lett., 41, 742-748, doi:10.1002/2013g1058392, 2014.

Lu, Z., Streets, D. G., Zhang, Q., Wang, S., Carmichael, G. R., Cheng, Y. F., Wei, C., Chin, M., Diehl, T., and Tan, Q.: Sulfur dioxide emissions in China and sulfur trends in East Asia since 2000, Atmos. Chem. Phys., 10, 6311-6331, doi:10.5194/acp-106311-2010, 2010.

Marlier, M. E., Voulgarakis, A., Shindell, D. T., Faluvegi, G., Henry, C. L., and Randerson, J. T.: The role of temporal evolution in modeling atmospheric emissions from tropical fires, Atmos. Environ., 89, 158-168, doi:10.1016/j.atmosenv.2014.02.039, 2014.

Matichuk, R. I., Colarco, P. R., Smith, J. A., and Toon, O. B.: Modeling the transport and optical properties of smoke aerosols from African savanna fires during the Southern African Regional Science Initiative campaign (SAFARI 2000), J. Geophys. Res., 112, D08203, doi:10.1029/2006JD007528, 2007.
Muller, J. F. and Brasseur, G.: Images - a 3-Dimensional ChemicalTransport Model of the Global Troposphere, J. Geophys. Res.Atmos., 100, 16445-16490, doi:10.1029/94jd03254, 1995.

Myhre, G., Samset, B. H., Schulz, M., Balkanski, Y., Bauer, S., Berntsen, T. K., Bian, H., Bellouin, N., Chin, M., Diehl, T., Easter, R. C., Feichter, J., Ghan, S. J., Hauglustaine, D., Iversen, T., Kinne, S., Kirkevåg, A., Lamarque, J.-F., Lin, G., Liu, X., Lund, M. T., Luo, G., Ma, X., van Noije, T., Penner, J. E., Rasch, P. J., Ruiz, A., Seland, Ø., Skeie, R. B., Stier, P., Takemura, T., Tsigaridis, K., Wang, P., Wang, Z., Xu, L., Yu, H., Yu, F., Yoon, J.-H., Zhang, K., Zhang, H., and Zhou, C.: Radiative forcing of the direct aerosol effect from AeroCom Phase II simulations, Atmos. Chem. Phys., 13, 1853-1877, doi:10.5194/acp-13-18532013, 2013.

Nabat, P., Somot, S., Mallet, M., Chiapello, I., Morcrette, J. J., Solmon, F., Szopa, S., Dulac, F., Collins, W., Ghan, S., Horowitz, L. W., Lamarque, J. F., Lee, Y. H., Naik, V., Nagashima, T., Shindell, D., and Skeie, R.: A 4-D climatology (1979-2009) of the monthly tropospheric aerosol optical depth distribution over the Mediterranean region from a comparative evaluation and blending of remote sensing and model products, Atmos. Meas. Tech., 6, 1287-1314, doi:10.5194/amt-6-1287-2013, 2013.

Omar, A. H., Winker, D. M., Vaughan, M. A., Hu, Y., Trepte, C. R., Ferrare, R. A., Lee, K.-P., Hostetler, C. A., Kittaka, C., Rogers, R. R., Kuehn, R. E., and Liu, Z.: The CALIPSO Automated Aerosol Classification and Lidar Ratio Selection Algorithm, J. Atmos. Ocean. Technol., 26, 1994-2014, doi:10.1175/2009jtecha1231.1, 2009.

Ott, W. R.: A physical explanation of the lognormality of pollutant concentrations, J. Air Waste Manage. Assoc., 40, 1378-1383, doi:10.1080/10473289.1990.10466789, 1990.

Petrenko, M., Kahn, R., Chin, M., Soja, A., Kucsera, T., and Harshvardhan: The use of satellite-measured aerosol optical depth to constrain biomass burning emissions source strength in the global model GOCART, J. Geophys. Res.-Atmos., 117, D18212, doi:10.1029/2012JD017870, 2012.

Prospero, J. M., Ginoux, P., Torres, O., Nicholson, S. E., and Gill, T. E.: Environmental characterization of global sources of atmospheric soil dust identified with the Nimbus 7 Total Ozone Mapping Spectrometer (TOMS) absorbing aerosol product, Rev. Geophys., 40, 1002, doi:10.1029/2000rg000095, 2002.

Regayre, L. A., Pringle, K. J., Booth, B. B. B., Lee, L. A., Mann, G. W., Browse, J., Woodhouse, M. T., Rap, A., Reddington, C. L., and Carslaw, K. S.: Uncertainty in the magnitude of aerosolcloud radiative forcing over recent decades, Geophys. Res. Lett., 41, 9040-9049, doi:10.1002/2014g1062029, 2014.

Ridley, D. A., Heald, C. L., and Ford, B.: North African dust export and deposition: A satellite and model perspective, J. Geophys. Res., 117, D02202, doi:10.1029/2011JD016794, 2012.

Russell, P. B., Kacenelenbogen, M., Livingston, J. M., Hasekamp, O. P., Burton, S. P., Schuster, G. L., Johnson, M. S., Knobelspiesse, K. D., Redemann, J., Ramachandran, S., and Holben, B.: A multiparameter aerosol classification method and its application to retrievals from spaceborne polarimetry, J. Geophys. Res.Atmos., 119, 9838-9863, doi:10.1002/2013jd021411, 2014.

Satoh, M., Matsuno, T., Tomita, H., Miura, H., Nasuno, T., and Iga, S.: Nonhydrostatic icosahedral atmospheric model (NICAM) for global cloud resolving simulations, J. Comput. Phys., 227, 34863514, doi:10.1016/j.jcp.2007.02.006, 2008. 
Satoh, M., Tomita, H., Yashiro, H., Miura, H., Kodama, C., Seiki, T., Noda, A., Yamada, Y., Goto, D., Sawada, M., Miyoshi, T., Niwa, Y., Hara, M., Ohno, T., Iga, S.-i., Arakawa, T., Inoue, T., and Kubokawa, H.: The Non-hydrostatic Icosahedral Atmospheric Model: description and development, Prog. Earth Planet. Sci., 1, 18, doi:10.1186/s40645-014-0018-1, 2014.

Schulz, M., Textor, C., Kinne, S., Balkanski, Y., Bauer, S., Berntsen, T., Berglen, T., Boucher, O., Dentener, F., Guibert, S., Isaksen, I. S. A., Iversen, T., Koch, D., Kirkevåg, A., Liu, X., Montanaro, V., Myhre, G., Penner, J. E., Pitari, G., Reddy, S., Seland, $\varnothing .$, Stier, P., and Takemura, T.: Radiative forcing by aerosols as derived from the AeroCom present-day and pre-industrial simulations, Atmos. Chem. Phys., 6, 5225-5246, doi:10.5194/acp-65225-2006, 2006.

Shindell, D. T., Lamarque, J.-F., Schulz, M., Flanner, M., Jiao, C., Chin, M., Young, P. J., Lee, Y. H., Rotstayn, L., Mahowald, N., Milly, G., Faluvegi, G., Balkanski, Y., Collins, W. J., Conley, A. J., Dalsoren, S., Easter, R., Ghan, S., Horowitz, L., Liu, X., Myhre, G., Nagashima, T., Naik, V., Rumbold, S. T., Skeie, R., Sudo, K., Szopa, S., Takemura, T., Voulgarakis, A., Yoon, J.-H., and Lo, F.: Radiative forcing in the ACCMIP historical and future climate simulations, Atmos. Chem. Phys., 13, 2939-2974, doi:10.5194/acp-13-2939-2013, 2013

Streets, D. G., Fu, J. S., Jang, C. J., Hao, J., He, K., Tang, X., Zhang, Y., Wang, Z., Li, Z., Zhang, Q., Wang, L., Wang, B., and Yu, C.: Air quality during the 2008 Beijing Olympic Games, Atmos. Environ., 41, 480-492, 2007.

Suzuki, K., Nakajima, T., Satoh, M., Tomita, H., Takemura, T., Nakajima, T. Y., and Stephens, G. L.: Global cloud-systemresolving simulation of aerosol effect on warm clouds, Geophys. Res. Lett., 35, L19817, doi:10.1029/2008g1035449, 2008.

Takemura, T., Okamoto, H., Maruyama, Y., Numaguti, A., Higurashi, A., and Nakajima, T.: Global three-dimensional simulation of aerosol optical thickness distribution of various origins, J. Geophys. Res.-Atmos., 105, 17853-17873, doi:10.1029/2000jd900265, 2000.

Takemura, T., Nakajima, T., Dubovik, O., Holben, B. N., and Kinne, S.: Single-scattering albedo and radiative forcing of various aerosol species with a global threedimensional model, J. Climate, 15, 333-352, doi:10.1175/15200442(2002)015<0333:SSAARF>2.0.CO;2, 2002.

Takemura, T., Nozawa, T., Emori, S., Nakajima, T. Y., and Nakajima, T.: Simulation of climate response to aerosol direct and indirect effects with aerosol transport-radiation model, J. Geophys. Res.-Atmos., 110, D02202, doi:10.1029/2004jd005029, 2005.

Taylor, K. E., Stouffer, R. J., and Meehl, G. A.: An Overview of CMIP5 and the Experiment Design, B. Am. Meteorol. Soc., 93, 485-498, doi:10.1175/BAMS-D-11-00094.1, 2012.
Teixeira, J., Waliser, D., Ferraro, R., Gleckler, P., Lee, T., and Potter, G.: Satellite observations for CMIP5: The genesis of Obs4MIPs, B. Am. Meteorol. Soc., 95, 1329-1334, doi:10.1175/Bams-D12-00204.1, 2014.

Tilmes, S., Lamarque, J.-F., Emmons, L. K., Kinnison, D. E., Ma, P.-L., Liu, X., Ghan, S., Bardeen, C., Arnold, S., Deeter, M., Vitt, F., Ryerson, T., Elkins, J. W., Moore, F., Spackman, J. R., and Val Martin, M.: Description and evaluation of tropospheric chemistry and aerosols in the Community Earth System Model (CESM1.2), Geosci. Model Dev., 8, 1395-1426, doi:10.5194/gmd-8-13952015, 2015.

van der Werf, G. R., Randerson, J. T., Giglio, L., Collatz, G. J., Mu, M., Kasibhatla, P. S., Morton, D. C., DeFries, R. S., Jin, Y., and van Leeuwen, T. T.: Global fire emissions and the contribution of deforestation, savanna, forest, agricultural, and peat fires (19972009), Atmos. Chem. Phys., 10, 11707-11735, doi:10.5194/acp10-11707-2010, 2010.

Veira, A., Kloster, S., Schutgens, N. A. J., and Kaiser, J. W.: Fire emission heights in the climate system - Part 2: Impact on transport, black carbon concentrations and radiation, Atmos. Chem Phys., 15, 7173-7193, doi:10.5194/acp-15-7173-2015, 2015.

Wang, L., Jang, C., Zhang, Y., Wang, K., Zhang, Q., Streets, D., Fu, J., Lei, Y., Schreifels, J., He, K., Hao, J., Lam, Y.-F., Lin, J., Meskhidze, N., Voorhees, S., Evarts, D., and Phillips, S.: Assessment of air quality benefits from national air pollution control policies in China. Part II: Evaluation of air quality predictions and air quality benefits assessment, Atmos. Environ., 44, 34493457, doi:10.1016/j.atmosenv.2010.05.058, 2010.

Wang, Y., Wang, M. H., Zhang, R. Y., Ghan, S. J., Lin, Y., Hu, J. X., Pan, B. W., Levy, M., Jiang, J. H., and Molina, M. J.: Assessing the effects of anthropogenic aerosols on Pacific storm track using a multiscale global climate model, P. Natl. Acad. Sci. USA, 111, 6894-6899, doi:10.1073/pnas.1403364111, 2014.

Yu, H. B., Remer, L. A., Chin, M., Bian, H. S., Kleidman, R. G., and Diehl, T.: A satellite-based assessment of transpacific transport of pollution aerosol, J. Geophys. Res.-Atmos., 113, D14S12, doi:10.1029/2007jd009349, 2008.

Zhang, R. Y., Li, G. H., Fan, J. W., Wu, D. L., and Molina, M. J.: Intensification of Pacific storm track linked to Asian pollution, P. Natl. Acad. Sci. USA, 104, 5295-5299, doi:10.1073/pnas.0700618104, 2007. 